\title{
Declaring cure in women with gonorrhoea
}

\author{
J A APAYA AND SAKINA RASHID
}

From the Department of Genitourinary Medicine, District General Hospital, Sunderland

SUMMARY The case notes of 426 women who had been treated for uncomplicated gonorrhoea in 1978-83 inclusive, were studied. The findings for 1978 formed a retrospective basis for a prospective study. The aim was to appraise the value of earlier and fewer follow up tests of cure. The new routine was associated with a more assertive approach to other modalities of control.

It was concluded that the interests of individual patients, as well as those aimed at control, were adequately served by one set of smear and culture specimens. There was one proviso. Potential "repeaters" need to be identified and treated individually in terms of follow up testing.

\section{Introduction}

Since 1977 it has been increasingly emphasised that two sets of smears and cultures are sufficient to establish or exclude a diagnosis of gonorrhoea in women. ${ }^{1-4}$ The recommendation is based on reciprocal and constant evaluation of clinic and supporting laboratory methods and adequate sampling of multiple sites. $^{356}$ In some areas special attention has been paid to culture media and the use of immunofluorescence to speed up diagnosis. ${ }^{1}$

Precision contrasts with recommendations designed to ensure cure. Current British textbooks recommend three or more tests over three months. Thin ${ }^{7}$ recommends urethral and cervical smears and cultures at 1-3, 7 , and 14 days after treatment: if these cultures are positive rectal specimens are also taken before treatment.

Schofield ${ }^{8}$ recommended tests over three months; twice within a week of treatment, then weekly for three successive weeks. Further smears and cultures are recommended after the next two menstrual periods. Patients treated during pregnancy are retested for at least three months. Three consecutive cultures are recommended for patients treated for gonococcal proctitis or pharyngitis. King et al ${ }^{9}$ advised three sets of tests, the last one preferably after menstruation.

Two retrospective studies published in 1976 agreed that testing after treatment was neither productive nor cost effective. ${ }^{1011}$ Evans $^{10}$ emphasised the "paramount importance" of contact tracing, and Chipperfield and Catterall ${ }^{11}$ emphasised the need to exclude reinfection

Address for reprints: Dr J A Apaya, Department of Genitourinary Medicine, Suite 3, Chesterfield and North Derbyshire Royal Hospital, Calow, Chesterfield S44 5BL

Accepted for publication 13 February 1986 exclude reinfection by undisclosed, untraced, and untreated asymptomatic contacts.

This prospective study aimed to appraise to findings of an updated approach to the follow up of women treated for gonorrhoea. This attempt to declare cure as soon as possible was prompted by: the managerial problems of growing demands by an increasing number of patients and a widening variety of sexual infections; the opportunity for improved control of gonorrhoea presented by declining prevalence of the infection in western countries; and the need to test the recommendations of others. ${ }^{1011}$

\section{Patients and methods}

Retrospective study of patients treated in 1978 formed the base line of comparison. The prospective part of the study ran from 1 January 1979 to 31 December 1983. The diagnositc methods and their evaluation were the same as those described elsewhere. ${ }^{1356}$ Smear and culture specimens were taken routinely from urethra, endocervix, and rectal wall. The pharynx was sampled selectively for culture alone. Smears were Gram stained and examined immediately. Culture specimens were transferred in Amies' medium twice daily for prompt "plating out" as described by Martin et al. ${ }^{12}$ Women named as contacts who had been undiagnosed by smear at the first attendance, were invited to reattend after 24 hours or as soon thereafter as was convenient. Thus an early presumptive diagnosis, made on the findings of intracellular or extracellular Gram negative diplococci, was the primary objective. Diagnosis by culture was available within 48-72 hours - that is, after 48 hours' incubation. Typical colony morphology, Gram stained appearance of the cultured organism, and sugar fermentation 
tests were the routine confirmatory procedures. All strains relatively resistant to penicillin (minimum inhibitory concentration (MIC) $=0.125 \mathrm{~g} / 1$ or more) were tested for $\beta$ lactamase activity by the chromogenic cephalosporin test. Smear and culture results were reciprocally evaluated as a routine ${ }^{1}$ and the antibiotic sensitivity findings were reviewed periodically. ${ }^{13}$ The methods of diagnosis thus gave a level of confidence that virtually eliminated the need for a thid set of diagnostic tests, or the need for epidemiological treatment. ${ }^{11}$

The preferred treatment throughout the years 197883 was a single intramuscular injection of $2 \cdot 4$ MIU of aqueous procaine penicillin with $1 \mathrm{~g}$ of probenecid orally: this offered a cure rate of around $98 \%$.

Adequate laboratory methods and cure rate led to the suggestion that from 1 January 1979 , the number of follow up tests could probably be cut from three to two without prejudice to patients or epidemiological control. The aim was to carry out the first set of tests three (instead of seven) days after treatment, or as soon as could be agreed, and to carry out the second test after a further week. This routine aimed to minimise default, detect treatment failures as quickly as possible, facilitate differentiation of treatment failures from reinfections, offer opportunities for early reinterviews regarding sexual contacts, and reinforce educational endeavours by showing an interest in an early declaration of cure.

As part of the prospective study, patient education and contact tracing were intensified. Each patient was informed by the doctor of her diagnosis, its personal implications, possible complications, the need for follow up tests, and the epidemiological issues entailed. This was re-emphasised, together with the confidential nature of care, by the health adviser, when she in turn interviewed the patient to collect contact data and to counsel regarding associated social or marital problems. Using contact slips, the patients' co-operative was sought to secure the earliest possible attendance of contacts. Reinterview at the earlier follow up testing times offered an opportunity to thank patients for their co-operation, collect promised contact data, repeat procedures for data collection, or agree the need for the health adviser to seek actively the contact(s) by telephone, letters, or visits or a combination of all these. Similar prompt attention was given to defaulting "culture positive" cases and those defaulting from follow up.From October 1983 patient education was expanded by the issue of fact sheets.

The number of patients studied totalled 426 , with 60 in the retrospective part (1978) and 366 in the prospective part (1979-83 inclusive).

\section{Results}

Table I shows that the proportion of patients reattend-
TABLE I Women with uncomplicated gonorrhoea: attendance for follow up tests 1978-83

\begin{tabular}{lrlrl}
\hline \multicolumn{7}{c}{ No (\%) attending: } \\
\cline { 3 - 5 } Year & $n$ & $\begin{array}{l}\text { First } \\
\text { follow up }\end{array}$ & $\begin{array}{l}\text { Second } \\
\text { follow up }\end{array}$ & \multicolumn{1}{l}{$\begin{array}{l}\text { No } \\
\text { follow up }\end{array}$} \\
\hline 1978 & 60 & $48(80)$ & $36(60)$ & $12(20)$ \\
1979 & 100 & $87(87)$ & $71(71)$ & $13(13)$ \\
1980 & 58 & $51(88)$ & $43(74)$ & $8(13)$ \\
1981 & 60 & $55(92)$ & $45(75)$ & $5(8)$ \\
1982 & 79 & $72(91)$ & $58(73)$ & $7(9)$ \\
1983 & 69 & $66(96)$ & $54(78)$ & $3(4)$ \\
$1979-83$ & 366 & $331(90)$ & $271(74)$ & $36(10)$ \\
\hline
\end{tabular}

ing for one follow up test increased steadily from 80 in 1978 to $95 \%$ in 1983 , with an average for $1978-83$ of $90 \%$. Table II shows the number agreeing to attend

TABLE II First follow up 3-7 days after treatment

\begin{tabular}{lll}
\hline Year & $\begin{array}{l}\text { No of patients } \\
\text { asked }\end{array}$ & No (\%) attending \\
\hline 1978 (at seven days) & 43 & $26(60 \cdot 5)$ \\
1979 three to seven days & 98 & $75(76 \cdot 5)$ \\
1980 three to seven days & 58 & $47(81 \cdot 0)$ \\
1981 three to seven days & 57 & $48(84 \cdot 2)$ \\
1982 three to seven days & 70 & $62(88 \cdot 6)$ \\
1983 three to seven days & 65 & $58(89 \cdot 2)$ \\
\hline
\end{tabular}

for their first test seven days after treatment (the routine in 1978), together with the number and percentage who complied. For comparison with the subsequent years, the table shows the numbers agreeing to reattend for a first test between three and seven days after treament, together with the number and percentage complying. The increase went from $61 \%$ in 1978 to $89 \%$ in 1983 , with an average for the prospective years of $84 \%$.

TABLE III Results of first follow up test

\begin{tabular}{lrll}
\hline & & \multicolumn{2}{l}{ No $(\%):$} \\
\cline { 3 - 4 } Year & $n$ & Negative & Positive \\
\hline 1978 & 48 & $46(95 \cdot 8)$ & $2(4 \cdot 2)$ \\
1979 & 87 & $87(100)$ & \\
1980 & 51 & $48(98)$ & $1(2)$ \\
1981 & 55 & $54(98 \cdot 2)$ & $1(1 \cdot 8)$ \\
1982 & 72 & $71(98 \cdot 6)$ & $1(1 \cdot 4)$ \\
1983 & 66 & $66(100)$ & \\
$1979-83$ & 331 & $326(99 \cdot 1)$ & $5^{*}(0 \cdot 9)$ \\
\hline
\end{tabular}

* One reinfection in 1978 and four treatment failures.

Table III shows the cure rate at first follow up test for each study year, together with the distribution of cases found to be smear or culture positive, or both: 
table IV details the five cases concerned. Four were diagnosed as treatment failures and one as a case of reinfection. Of the 374 patients giving negative results at the first follow up testing, $307(82 \%$, or $73 \%$ of the total 426) reattended.

Table I shows that whereas in $197860 \%$ reattended for a second test, the percentage increased steadily from 1979 to 1983 to average $74 \%$ for these years.

Table $\mathrm{V}$ shows the cure rate for each study year, as judged by the second testing, together with the distribution of cases found to be smear or culture positive, or both: table VI details the five cases concerned. All were designated reinfections. In all, 48 (11.2\%) treated patients defaulted immediately and completely. In 1978 the percentage was 20 , a figure
TABLE $\mathrm{v}$ Results of second follow up tests (figures in parentheses are numbers (\%))

\begin{tabular}{lrll}
\hline & & \multicolumn{1}{l}{ No (\%): } \\
\cline { 3 - 4 } Year & $n$ & Negative & Positive \\
\hline 1978 & 36 & $36(100)$ & \\
1979 & 71 & $68(95 \cdot 8)$ & $3(4 \cdot 2)$ \\
1980 & 43 & $43(100)$ & $1(2 \cdot 2)$ \\
1981 & 45 & $44(97 \cdot 8)$ & \\
1982 & 58 & $58(100)$ & $1(1 \cdot 9)$ \\
1983 & 54 & $53(98 \cdot 1)$ & $5^{*}(1 \cdot 8)$ \\
$1979-83$ & 271 & $266(98 \cdot 2)$ &
\end{tabular}

*All five were designated reinfections.

TABLE IV Details of patients requiring retreatment after first follow up test

\begin{tabular}{|c|c|c|c|c|c|c|}
\hline $\begin{array}{l}\text { Case } \\
\text { No }\end{array}$ & $\begin{array}{l}\text { Sites } \\
\text { tested }\end{array}$ & $\begin{array}{l}\text { Initial } \\
\text { diagnostic tests }\end{array}$ & First follow up & $\begin{array}{l}\text { Sexual intercourse } \\
\text { after treatment }\end{array}$ & Remarks & Verdict \\
\hline 1 & $\begin{array}{l}\text { Urethra } \\
\text { Cervix } \\
\text { Rectal wall }\end{array}$ & $\begin{array}{l}\text { Positive } \\
\text { Positive } \\
\text { Positive } \\
\text { Sensitive to } \\
\text { penicillin* }\end{array}$ & $\begin{array}{l}\text { Negative } \\
\text { Negative } \\
\text { Positive } \\
\text { Sensitive to } \\
\text { pencillin* }\end{array}$ & Denied & $\begin{array}{l}\text { Positive (rectal) } 1 / 52 \\
\text { after treatment. Responded } \\
\text { to double dose penicillin, } \\
\text { two subsequent cultures } \\
\text { negative }\end{array}$ & $\begin{array}{l}\text { Treatment } \\
\text { failure }\end{array}$ \\
\hline 2 & $\begin{array}{l}\text { Urethra } \\
\text { Cervix } \\
\text { Rectal wall }\end{array}$ & $\begin{array}{l}\text { Negative } \\
\text { Positive } \\
\text { Negative } \\
\text { Sensitive to } \\
\text { pencillin* }\end{array}$ & $\begin{array}{l}\text { Negative } \\
\text { Positive } \\
\text { Negative } \\
\text { Sensitive to } \\
\text { pencillin* }\end{array}$ & $\begin{array}{l}\text { Admitted re-exposure } \\
\text { fifth day after } \\
\text { treatment; same } \\
\text { named untreated } \\
\text { partner }\end{array}$ & $\begin{array}{l}\text { Defaulted; retested } 3 / 52 \\
\text { after treatment, partner } \\
\text { also infected; both responded } \\
\text { to routine penicillin regimen }\end{array}$ & Reinfection \\
\hline 3 & $\begin{array}{l}\text { Urethra } \\
\text { Cervix } \\
\text { Rectal wall }\end{array}$ & $\begin{array}{l}\text { Positive } \\
\text { Positive } \\
\text { Negative } \\
\text { Relatively resistant } \\
\text { to penicillin } \dagger \\
\text { (PPNG) }\end{array}$ & $\begin{array}{l}\text { Positive } \\
\text { Positive } \\
\text { Negative } \\
\text { Relatively resistant } \\
\text { to penicillin } \dagger \\
\text { (PPNG) }\end{array}$ & Denied & $\begin{array}{l}\text { Partner also positive } \\
\text { at first follow up (PPNG); } \\
\text { both cured with } \\
\text { spectinomycin }\end{array}$ & $\begin{array}{l}\text { Treatment } \\
\text { failure }\end{array}$ \\
\hline 4 & $\begin{array}{l}\text { Urethra } \\
\text { Cervix } \\
\text { Rectal wall }\end{array}$ & $\begin{array}{l}\text { Positive } \\
\text { Positive } \\
\text { Negative } \\
\text { Relatively resistant } \\
\text { to penicillin } \dagger\end{array}$ & $\begin{array}{l}\text { Positive } \\
\text { Positive } \\
\text { Negative } \\
\text { Relatively resistant } \\
\text { to penicillin } \dagger\end{array}$ & Denied & $\begin{array}{l}\text { Partner also positive at } \\
\text { first follow up } 3 / 7 \\
\text { (non-PPNG); both cured } \\
\text { with spectinomycin }\end{array}$ & $\begin{array}{l}\text { Treatment } \\
\text { failure }\end{array}$ \\
\hline 5 & $\begin{array}{l}\text { Urethra } \\
\text { Cervix } \\
\text { Rectal wall } \\
\text { Throat }\end{array}$ & $\begin{array}{l}\text { Negative } \\
\text { Negative } \\
\text { Negative } \\
\text { Positive } \\
\text { Relatively resistant } \\
\text { to penicillin } \dagger\end{array}$ & $\begin{array}{l}\text { Negative } \\
\text { Negative } \\
\text { Negative } \\
\text { Positive } \\
\text { Relatively resistant } \\
\text { to penicillin } \dagger\end{array}$ & Denied & $\begin{array}{l}\text { Partners urethra culture } \\
\text { positive again; resistant } \\
\text { (non-PPNG) strain. Both } \\
\text { responded to spectinomycin }\end{array}$ & $\begin{array}{l}\text { Treatment } \\
\text { failure }\end{array}$ \\
\hline
\end{tabular}

*Minimum inhibitory concentration (MIC) $=0.015 \mathrm{mg} / \mathrm{l}$

$+\mathrm{MIC}=0.125 \mathrm{mg} / \mathrm{l}$.

PPNG = Penicillinase producing Neisseria gonorrhoeae .

which fell steadily to $4 \%$ in 1983 , with an average of $10 \%$ for the prospective study years of $1979-83$ (table I).

One other finding noted as the "repeated rate"- that is, the percentage of patients who have more than one episode of gonococcal infection in any one year
(January 1 to December 31 ). The rates for the study years were $5 \%$ (1978); $8.5 \%$ (1979); $3.6 \%$ (1980); $5.8 \%(1981) ; 4.3 \%(1982)$; and $6 \%$ (1983). The average repeat rate for the prospective study years, $(5.5 \%)$ was almost the same as that of $1978(5 \%)$. The annual number of strains relatively resistant to 
TABLE VI Details of positive cases found at second follow up

\begin{tabular}{|c|c|c|c|c|c|c|c|}
\hline Case No & Sites tested & $\begin{array}{l}\text { Initial } \\
\text { diagnostic } \\
\text { tests }\end{array}$ & $\begin{array}{l}\text { First } \\
\text { follow up }\end{array}$ & $\begin{array}{l}\text { Second } \\
\text { follow up }\end{array}$ & $\begin{array}{l}\text { Treatment after } \\
\text { sex }\end{array}$ & Remarks & Verdict \\
\hline 1 & $\begin{array}{l}\text { Urethra } \\
\text { Cervix } \\
\text { Rectal wall }\end{array}$ & $\begin{array}{l}\text { Positive } \\
\text { Positive } \\
\text { Negative } \\
\text { Sensitive to } \\
\text { pencillin }\end{array}$ & $\begin{array}{l}\text { Negative } \\
\text { Negative } \\
\text { Negative }\end{array}$ & $\begin{array}{l}\text { Negative } \\
\text { Positive } \\
\text { Negative } \\
\text { Sensitive to } \\
\text { pencillin }\end{array}$ & $\begin{array}{l}\text { Admitted; same } \\
\text { untreated boyfriend } \\
\text { now positive }\end{array}$ & $\begin{array}{l}\text { Positive } 2 / 52 \text { after treatment; } \\
\text { boyfriend diagnosed positive; both } \\
\text { responded to same standard regime }\end{array}$ & Reinfection \\
\hline 2 & $\begin{array}{l}\text { Urethra } \\
\text { Cervix } \\
\text { Rectal wall }\end{array}$ & $\begin{array}{l}\text { Positive } \\
\text { Positive } \\
\text { Negative } \\
\text { Sensitive to } \\
\text { pencillin }\end{array}$ & $\begin{array}{l}\text { Negative } \\
\text { Negative } \\
\text { Negative }\end{array}$ & $\begin{array}{l}\text { Negative } \\
\text { Negative } \\
\text { Positive } \\
\text { Relatively } \\
\text { resistant to } \\
\text { penicillin }\end{array}$ & $\begin{array}{l}\text { Admitted; } \\
\text { different boyfriend } \\
\text { found infected, } \\
\text { resistant strain }\end{array}$ & $\begin{array}{l}\text { Defaulted, positive } 3 / 52 \text { after } \\
\text { negative cultures; both cured } \\
\text { by spectinomycin }\end{array}$ & Reinfection \\
\hline 3 & $\begin{array}{l}\text { Urethra } \\
\text { Cervix } \\
\text { Rectal wall }\end{array}$ & $\begin{array}{l}\text { Negative } \\
\text { Positive } \\
\text { Positive } \\
\text { Sensitive to } \\
\text { pencillin }\end{array}$ & $\begin{array}{l}\text { Negative } \\
\text { Negative } \\
\text { Negative }\end{array}$ & $\begin{array}{l}\text { Positive } \\
\text { Positive } \\
\text { Negative } \\
\text { Sensitive to } \\
\text { pencillin }\end{array}$ & $\begin{array}{l}\text { Admitted; same } \\
\text { boyfriend untreated; } \\
\text { now positive }\end{array}$ & $\begin{array}{l}\text { Cervix, and urethra positive } 3 / 52 \\
\text { after negative tests, sperm on } \\
\text { smears; both responded to penicillin }\end{array}$ & Reinfection \\
\hline 4 & $\begin{array}{l}\text { Urethra } \\
\text { Cervix } \\
\text { Rectal wall }\end{array}$ & $\begin{array}{l}\text { Positive } \\
\text { Positive } \\
\text { Negative } \\
\text { Sensitive to } \\
\text { pencillin }\end{array}$ & $\begin{array}{l}\text { Negative } \\
\text { Negative } \\
\text { Negative }\end{array}$ & $\begin{array}{l}\text { Negative } \\
\text { Negative } \\
\text { Positive } \\
\text { Sensitive to } \\
\text { pencillin }\end{array}$ & $\begin{array}{l}\text { Admitted, same } \\
\text { named untreated } \\
\text { partner }\end{array}$ & $\begin{array}{l}\text { Defaulted, positive } 11 \text { days after } \\
\text { negative cultures; both cured by } \\
\text { standard penicillin treatment }\end{array}$ & Reinfection \\
\hline 5 & $\begin{array}{l}\text { Urethra } \\
\text { Cervix } \\
\text { Rectal wall }\end{array}$ & $\begin{array}{l}\text { Positive } \\
\text { Positive } \\
\text { Negative } \\
\text { Sensitive to } \\
\text { pencillin }\end{array}$ & $\begin{array}{l}\text { Negative } \\
\text { Negative } \\
\text { Negative }\end{array}$ & $\begin{array}{l}\text { Negative } \\
\text { Negative } \\
\text { Positive } \\
\text { Relatively } \\
\text { resistant to } \\
\text { penicillin }\end{array}$ & $\begin{array}{l}\text { New partner, both } \\
\text { infections resistant } \\
\text { strains }\end{array}$ & $\begin{array}{l}2 / 52 \text { tetracycline after negative } \\
\text { follow up; first boyfriend chlamydia } \\
\text { positive, gonococcus negative, } \\
\text { patient positive } 3 / 52 \text { after negative } \\
\text { culture: both responded to } \\
\text { spectinomycin } 2 \mathrm{~g}\end{array}$ & Reinfection \\
\hline
\end{tabular}

penicillin proved to be too few to make their percentage a valid index of control, as suggested by Jackson and Jephcott. ${ }^{13}$

\section{Discussion}

Concentrating follow up tests immediately after treatment seems to have advantages. A higher percentage of patients return, cure can be declared within 10 days of treatment, and differentiating treatment failures from reinfection is facilitated. Apart from intensified patient education, we feel that the routine described engendered a shared sense of concern to declare cure as soon as possible. Our findings seem to suggest that time spent on the patient at the initial visit also reduces the need for recall of defaulters.

The Jembec culture studies combined with immunofluoresence confirmatory tests, as described by Morton and Jephcott, ${ }^{1}$ suggest that further improvements along the lines described are possible. In particular, treatment failures could be identified earlier, together with their sensitivity to penicillin. This is not only in the best interests of the individual patient but could, both directly and indirectly, prevent dissemination of relatively or completely penicillin resistant strains.
The earlier the first follow up test, with satisfactory results, the more confidently can reinfection be diagnosed. We feel it should be possible, for example, to say to a patient, "did you have intercourse on Saturday or Sunday?" rather than asking her if and when she last had intercourse.

Evans ${ }^{10}$ had 11 "positives" in 583 follow up tests in 86 patients. Most were believed to be the result of reinfections. Chipperfield and Catterall" found nine "positives" in $\$ 04$ follow up tests over several weeks. Like us, these workers wanted to apply more rational routines.

Advancing the first follow up test was welcomed by the health adviser. It helped her to instil in index patients a helpful sense of urgency about the attendance of contacts. This especially applied to uncooperative or dilatory patients, some of whom were already known to us as being potential repeaters. This aspect calls for evaluation research. By way of a bonus in recent years we found that the earlier return of patients for the first follow up tests means an earlier start to treatment for those found to have concomitant Chlamydia trachomatis infections.

As regards patient education, Goodrich, who had doubts about the clinical and economic justification of repeated tests of cure, did show that "educational 
counselling" greatly improved reattendance rates. ${ }^{14}$ Our experience leads us to a similar view. The size and epidemiological importance of the "repeater" problem has recently been addressed in America ${ }^{15}{ }^{16}$ and the United Kingdom. ${ }^{17}$ The last of these studies concluded that "repeaters" may comprise a constant proportion of the infected. Our findings confirm this and suggest that the constancy in terms of a figure may be inseparably associated with local morbidity. Much is still to be learned about the geography of gonorrhoea. Kinghorn et al $^{17}$ described the characteristics of their repeaters. Our modest experience also suggests that potential "repeaters" are an identifiable group calling for special attention in terms of follow up testing.

In conclusion, we recommend the earliest possible follow up of women who have been treated for gonorrhoea: it is managerially worthwhile as it leads to earlier declaration of cure, helps to differentiate treatment failure from reinfections, strengthens contact tracing endeavours, and more rapidly identifies and leads to cure of those with relatively and completely penicillin resistant gonococci. In a non-metropolitan clinic one prompt follow up testing of multiple sites should suffice for most women treated for gonorrhoea.

Such a routine, however, must go hand in hand with an awareness by all clinic staff of the need to identify potential repeaters and to ensure that they have at least two follow up tests.

We thank Dr RS Morton for helpful advice and Mrs A Harding for her patience with retyping.

\section{References}

1. Morton RS. Gonorrhoea. Philiadelphia: WB Saunders, 1977:246-8.
2. Young H, Harris AB, Urquhart D, Robertson DHH. Screening by culture for the detection of gonorrhoea in women. Scot Med J 1979;24:302.

3. Jephcott AE, Rashid S. Improved management in the diagnosis of gonorrhoea in women. British Journal of Venereal Diseases 1978;54:155.

4. Robertson DHH, McMillan A, Young H. In: Clinical practice in sexually transmissible diseases. 1st ed. London: Pitman Medical, 1980.

5. Bhattacharyya MM, Jephcott AE, Morton RS. Diagnosis of gonorrhoea in women: comparison of sampling sites. $\mathrm{Br} \mathrm{Med} \mathrm{J}$ 1973;ii:748-50.

6 Bhattacharyya MM, Jephcott AE. Diagnosis of gonorrhoea in women - role of the rectal sample. British Journal of Venereal Diseases 1974;50:109-12.

7 Thin R. In: Lecture notes in sexually transmitted diseases. 1 st ed. Edinburgh: Churchill Livingstone, 1982:123.

8 Schofield CBS. In: Sexually transmitted diseases. 3rd ed. Edinburgh: Churchill Lvingstone, 1979:152.

9. King A, Nicol C, Rodin P., In: Venereal diseases. 4th ed. London: Bailliere Tindal, 1980.

10. Evans BA. Detection of gonorrhoea in women. British Journal of Venereal Diseases 1976;52:40-2.

11. Chipperfield EJ, Catterall RD. Re-appraisal of Gram staining and cultural techniques for the diagnosis of gonorrhoea in women. British Journal of Venereal Diseases 1976;52:36-9.

12. Martin JE Jr, Billings TE, Hackney JF, Thayer JD. Primary isolation of Neisseria gonorrhoea with a new commercial medium. Public Health Rep 1967;82:381.

13. Jackson DH, Jephcott AE. Penicillin sensitivity of gonococci. An evaluation of monitoring as an index of epidemiological control. British Journal of Venereal Diseases 1976;52:253-5.

14. Goodrich KK. Gonococcal infection. The effect of educational counselling on patient compliance. British Journal of Venereal Diseases 1981;57:137-40.

15. Yorke JA, Hethcote HW, Nold A. Dynamics and control of transmission of gonorrhoea. Sex Transm Dis 1978;5:51-6.

16. Brooks GF, Dattow NW, Day JA. Repeated gonorrhoea: an analysis of importance and risk factors. J Infect Dis 1978;137:161-9.

17. Kinghorn GR, Pryce D, Morton RS. Repeated gonorrhoea in Sheffield. The size of the problem, epidemiologic significance and personal characterisitics of repeaters. Sex Transm Dis 1982;9:165-9. 